\title{
Modeling, dialogue, and globality: Biosemiotics and semiotics of self. 2. Biosemiotics, semiotics of self, and semioethics
}

\author{
Susan Petrilli \\ Dept. of Linguistic Practices and Text Analysis, University of Bari \\ Via Garruba 6, 70100 Bari, Italy \\ e-mail: s.petrilli@lingue.uniba.it
}

\begin{abstract}
The main approaches to semiotic inquiry today contradict the idea of the individual as a separate and self-sufficient entity. The body of an organism in the micro- and macrocosm is not an isolated biological entity, it does not belong to the individual, it is not a separate and self-sufficient sphere in itself. The body is an organism that lives in relation to other bodies, it is intercorporeal and interdependent. This concept of the body finds confirmation in cultural practices and worldviews based on intercorporeity, interdependency, exposition and opening, though nowadays such practices are almost extinct. An approach to semiotics that is global and at once capable of surpassing the illusory idea of definitive and ultimate boundaries to identity presupposes dialogue and otherness. Otherness obliges identity to question the tendency to totalizing closure and to reorganize itself always anew in a process related to 'infinity', as Emmanuel Levinas teaches us, or to 'infinite semiosis', to say it with Charles Sanders Peirce. Another topic of this paper is the interrelation in anthroposemiosis between man and machine and the implications involved for the future of humanity. Our overall purpose is to develop global semiotics in the direction of "semioethics", as proposed by S. Petrilli and A. Ponzio and their ongoing research.
\end{abstract}

\section{Dialogic interconnections among semiosic spheres}

Semiotics today has come a long way with respect to the science of signs as it had been conceived by Ferdinand de Saussure. In Semiotik/ Semiotics: A Handbook on the Sign-Theoretic Foundations of Nature and Culture, edited by Roland Posner, Klaus Robering, Thomas A. Sebeok, 1997-2003, semiotics is far broader than a science that 
focuses on signs in the sphere of socio-cultural life. Semiotics is not only anthroposemiotics but also endosemiotics (semiotics of cybernetic systems inside the organic body on the ontogenetic and phylogenetic levels), microsemiotics (the study of metabolism in unicellular life forms), mycosemiotics (semiotics of fungi), phytosemiotics (semiotics of plant life), zoosemiotics (semiotics of interactions among animals), machine semiotics (semiotics of sign processing machinery), environmental semiotics (the study of the interaction between different species and environment).

Main trends in semiotic inquiry today contradict the idea of the individual as a separate and self-sufficient entity. The body of an organism in the micro- and macrocosm is not an isolated biological entity, it does not belong to the individual, it is not a separate and selfsufficient sphere in itself. The body is an organism that lives in relation to other bodies, it is intercorporeal and interdependent. This concept of the body finds confirmation in cultural practices and worldviews based on intercorporeity, interdependency, exposition and opening, though nowadays such practices are almost extinct (what remains are mummified, archeological residues studied by folklore analysts or preserved in ethnological museums and in the histories of national literature).

Think of how the body is perceived in popular culture, the forms of 'grotesque realism', as discussed by Mikhail Bakhtin (1963; 1965). In such contexts the life of the body is not conceived in individual terms, that is, separately from life over the planet, indeed from the world in its globality. However, only very weak traces of the grotesque body have survived in the present day. We are alluding to such signs as ritual masks, masks used during popular festivities, carnival masks. According to grotesque realism the contours of the body are undefined. In other words, the body is not confined to itself, but rather flourishes in relations of symbiosis with other bodies, in processes of transformation and renewal that transcend the limits of individual life. 'Grotesque realism' is characteristic of medieval popular culture indicating a condition preexistent to the development of individualism in relation to the rise of bourgeois society, to the development of an individualistic conception of the body. However, we wish to underline what would seem to be a paradox - in today's society of world and global communication this individualistic, private and static conception of the body has in fact been reinforced and exasperated. 
An approach to semiotics that is at once global and detotalizing presupposes dialogue and otherness. In other words, global semiotics presupposes the capacity for listening to the other, a disposition for opening to others, for listening to others in their otherness, for hospitality. According to such logic, opening is not only understood in the quantitative sense (that is, with reference to the omnicomprehensive character of global semiotics), but also in the qualitative sense. Otherness obliges the totality to reorganize itself ever anew in a process related to 'infinity', as Emmanuel Levinas teaches us, or to 'infinite semiosis', to say it with Charles S. Peirce. This relation to infinity is far more than cognitive: beyond the established order, beyond the symbolic order, beyond our conventions and habits, it presupposes a relation of involvement and responsibility. The relation to infinity is a relation to what is most refractory to the totality, a relation to the otherness of others, of the other person. And the expression 'other person' is not understood in the sense of another Self like ourselves, another alter ego, an I belonging to the same community, but another in its extraneousness, strangeness, diversity, the alien self. This is also a question of difference that Self cannot ignore, towards which it cannot be indifferent in spite of all efforts and guarantees offered by identity.

As anticipated by Augusto Ponzio (2003), all semiotic interpretations by the student of signs must keep account of the dialogic character of the relation with the other. In fact, dialogism is a fundamental condition for an approach to semiotics that is oriented according to a global perspective with a tendency to privilege and enhance the particular and the local rather than englobe or enclose it.

\section{Sebeok's contribution to semiotics}

Following a suggestion from Thomas A. Sebeok as may be deduced from the chapter title 'Looking in the destination for what should have been sought in the source', included in The Sign \& Its Masters (Sebeok 1979: 84-106), the source we intend to research is the comprehensive view of semiotics presented by the general project subtending and orienting the Handbook Semiotik/Semiotics. We believe that this source coincides with Sebeok's own scientific and editorial work. Furthermore, he is one of the figures who has most contributed to promoting semiotics across the world through organizational activi- 
ties leading to the institutionalization of semiotics on an international level and to its current configuration in the world of academia and research.

We believe that the foundational scope of Semiotik/Semiotics coincides with Sebeok's own approach to semiotics - which is holistic, ecumenical, or, to use his most recent terminology, global. The editorial enterprise achieved with this Handbook would not have been possible without Sebeok's semiotic enquiry (and as much may be said about The Encyclopedia of Semiotics, edited by Paul Bouissac 1998). The terms 'zoosemiotics' and 'endosemiotics' were coined by Sebeok in 1963 and 1976 respectively (cf. Sebeok 2001: 20, 27). And though the term 'biosemiotics' already existed, Sebeok was a pioneer in this field as well, which he was committed to promoting (cf. the entry 'Biosemiotics' by Hoffmeyer 1998, which mentions Gregory Bateson as another scholar in this field). Sebeok was one of the editors of Semiotik/Semiotics, but more than this we believe he created the conditions which made the general plan of the Handbook possible. Consequently, some information in the present context about his research and the directions in which it developed will be appropriate.

Sebeok's interests cover a broad range of territories varying from the natural sciences to the human sciences (see Sebeok, 'Signs, bridges, origins', in Sebeok 2001: 59-73). Consequently, he deals with theoretical issues and their applications from as many angles as the number and variety of disciplines he interrogates: linguistics, cultural anthropology, psychology, artificial intelligence, zoology, ethology, biology, medicine, robotics, mathematics, philosophy, literature, narratology, and so forth. Initially Sebeok's research may seem rather erratic as he experiments different perspectives and embarks upon a plurality of different research ventures. However, the truth is that the broad scope of his interests come together in the focus of his 'doctrine of signs' and fundamental conviction subtending his general method of enquiry: the universe is perfused with signs, indeed, as Peirce hazards, it may even be composed exclusively of signs.

As a fact of signification the entire universe enters Sebeok's 'global semiotics' (see Sebeok 2001). Semiotics is the place where the 'life sciences' and the 'sign sciences' converge, therefore where consciousness is reached of the fact that the human being is a sign in a universe of signs. Says Sebeok in his 'Introduction' to Global Semiotics: 
In sum, global semiotics can bee seen as composed of two partially overlapping estates: 'normal' semiotics, as defined above, the subject matter of which is, intrinsically, Minds, Models, and Mediation; and biosemiotics, all this and much, much more, as presented throughout this book. Needless to point out, practitioners of the discipline may be qualified to work in one aspect or the other, or, as a rule, in one or more fractions of the supervening category. Scarce is the polymath of the magistral stature of, say, Charles Peirce, capable of reaching athwart more than a couple of divisions, especially across the humanities and the sciences, which are perhaps uniquely bridged by semiotics [...]. (Sebeok 2001: xxii)

Through his numerous publications Sebeok has propounded a wideranging vision of semiotics that coincides with the study of the evolution of life. After Sebeok's work both the conception of the semiotic field and history of semiotics are changed noticeably. Thanks to him semiotics at the beginning of the new millennium presents a far more expanded view than that of the first half of the 1960 s.

\section{Language in anthroposemiosis}

In Semiotik/Semiotics, Article 18, 'The evolution of semiosis', authored by Sebeok (1997), analyzes the origins of anthroposemiosis signaling its distinctive feature with respect to nonhuman zoosemiosis, namely language. Hominid forms, which evolved out of the australopithecines, include Homo habilis ('handy man', 2.4 to 2.0 million years ago), first described in 1964, which is the first hominid with a distinctly enlarged brain $\left(600-800 \mathrm{~cm}^{3}\right)$. It appears virtually certain that $H$. habilis had language, as an interior modeling device, although not speech. A modeling system is a tool with which an organism analyzes its surroundings. Language-as-a-modeling-system seems to have always been an exclusive property of the genus Homo. Members of early hominid species communicated with each other by nonverbal means, in the manner of all other primates. Homo erectus too ('upright man', over 1.5 million years ago) with a brain volume of 800-1,200 $\mathrm{cm}^{3}$ and a far more elaborate tool kit, including fire, had language, yet not speech (cf. Sebeok 1997: 443; see also Sebeok 1986; 1991a; 1994).

Thus while language as a specific human primary modeling system emerged on the scene perhaps 2.5 or even 3.0 million years ago circa, verbal language or speech appeared solely in Homo sapiens as a 
communication system and gradually as a cognitive system, that is, a secondary modeling system, with the appearance of Homo sapiens sapiens.

Emphasizing the species-specific character of human language, Sebeok (with Jean Umiker-Sebeok) intervened polemically and ironically as regards the general enthusiasm (which he attempted to cool down) for theories and practices developed for training animals on the basis of the assumption that they too are endowed with a capacity for speech (cf. Sebeok 1986: Ch. 2). Also, the distinction between language and speech together with the thesis that language appeared much earlier than speech in the evolution of the human species reinforce the critique of phonocentrism. Language cannot be reduced to a mere communicative device (on this point Sebeok is in accord with Chomsky, though the latter does not clearly distinguish between language and speech). Said differently, in the evolution of anthroposemiosis the specific function of language is not to transmit messages and give information.

All species communicate in a world that is specific to the species and that ensues from the type of modeling with which a given species is endowed (cf. J. v. Uexküll 1992). Very early in its development as a hominid, the human species was endowed with a modeling device capable of producing an infinite number of worlds. This explains the evolution of hominids into Homo sapiens sapiens. The reason why human animals are able to produce an unlimited number of worlds is that the human modeling device, or language, functions in terms of syntax. In other words, a finite number of elements are composed and recomposed in an infinite variety of ways in construction, deconstruction and reconstruction processes. The multiplicity of languages and of elements (or dimensions) forming each one of them (the phonological, syntactic, semantic) all depend on this modeling device. Therefore, thanks to this syntactic capacity that which is organized in a given way can be reorganized differently. The human modeling device is endowed with syntax and is capable of the work of bricolage.

Thanks to his studies on la pensée sauvage, Claude Lévi-Strauss may be counted among those researchers who have most contributed to identifying and illuminating the workings of such a special human capacity. 


\section{Syntax and human semiosis as semiotics}

The capacity for syntax, for reorganization presupposes the capacity for reflection. In other words, thanks to language human beings are capable of reflecting on materials, means and models, and consequently of engendering new modeling processes with the same materials. This capacity for reflection is the capacity for metasemiosis, or what we propose to call semiotics. In this sense, language and, therefore, the work of syntax is semiotical.

At this point we must specify that when we speak of 'syntax' we are not just referring to one of the three dimensions of semiotics, that is, syntactics, as opposed to the other two dimensions, that is, semantics and pragmatics, as described by Charles Morris (1938; Posner, Robering 1997; Robering 1997; Posner 1997b; Münch, Posner 1998). Syntax is part of each of the three 'dimensions'. Or, if in relation to verbal language we consider 'grammar' as formed of a phonological, semantic and syntactic component along the lines proposed by Noam Chomsky, syntax is also present in the other two components. The syntax of phonemes gives rise to monemes, and the syntax of monemes gives rise to the words of a language even before words (categorematic and syncategorematic terms) are organized by syntax properly understood. Consequently, syntax is language itself considered from the viewpoint of its constructive, deconstructive and reconstructive capacity, just as semiotics is language considered in terms of its capacity for metasemiosis.

By virtue of its syntactic component, language does not represent immediate reality. From this point of view Sebeok (1991a: 57-58) observes that language is, properly speaking, a secondary modeling system. Instead, the relatively simple, nonverbal models activated by nonhuman animals and likewise by human infants are examples of primary modeling. The models in question here are more or less pliable representations that must fit 'reality' sufficiently to tend to secure survival in one's Umwelt.

Such 'top-down' modeling (to use a current jargon borrowed from the cognitive sciences) can persist, and become very sophisticated indeed in the adult life of exceptionally gifted individuals, as borne out by Einstein's testimonial or by what we know about Mozart's or Picasso's ability to model intricate auditory or visual compositions in their heads in anticipation of transcribing this onto paper canvas. This kind of nonverbal modeling is indeed primary, in both a phylogenetic and an ontogenetic sense. [...] Syntax makes 
it possible for hominids not only to represent immediate 'reality' (in the sense discussed above) but also, uniquely among animals, to frame an indefinite number of possible worlds in the sense of Leibniz. (Sebeok 1991a: 57-58)

In his article 'Evolution of semiosis', Sebeok (1997) briefly mentions the 'exaptation' processes of language into speech (and into other manifestations such as script), and vice versa of speech into language. In other works, Sebeok deals with adaptation and exaptation in language and speech, which being pivotal processes in the evolution of anthroposemiosis are topics that belong to anthroposemiotics (cf. Sebeok 1991a). 'Exaptation' is a term coined by paleontologists Stephen Jay Gould and Elizabeth Vrba as a counterpart to the Darwinian notion of 'adaptation'. Encyclopedia of Semiotics includes the entry 'Exaptation' (by Michael Ruse who is also the author of the entry 'Evolution'; Ruse 1998a; 1998b). Two types of exaptation have been identified: in fact, exaptation processes may arise either in a situation in which 'a character, previously shaped by natural selection for a particular function (an adaptation), is coopted for a new use' or when 'a character whose origin cannot be ascribed to the direct action of natural selection [...] is coopted for a current use' (Gould, Vrba 1982: 5). Observes Ruse:

The idea of an exaptation is one with obvious implications for any biological theory of communication, such as that of Noam Chomsky, which wants to locate language in evolution but has trouble seeing how the Darwinian mechanism of natural selection can do all that is required. (Ruse 1998b: 226)

The plurality of natural languages (as well as the 'inner plurilingualism' of any single natural language) cannot be explained (the 'Babel enigma') in terms of Chomsky's linguistics in spite of his insistence on the 'creative character of (verbal) language', given that his approach presupposes an innate Universal Grammar. Such phenomena as the plurality of languages and 'linguistic creativity' testify to the capacity of language, understood as a primary modeling device, for producing numerous possible worlds. Both phenomena ensue from the fact that human modeling is able to invent manifold worlds. In other words, linguistic creativity as well as the plurality of languages derive from the gift of language for the 'play of musement'. 'Purport', according to Hjelmslev (1953: 32-33) is an amorphous continuum 'on which boundaries are laid by the formative action of language'. Language articulates the shapeless purport of expression and content 
in different ways in different languages. For instance, the human phonic material of purport is divided into different figurae (phonemes) by different languages; and the color continuum is also divided differently, e.g. in English or Welsh (see Johansen 1998: 2275-2282). All this may be explicated on the basis of creativity characterizing language understood as a species-specific human modeling device. To use Ferruccio Rossi-Landi's terminology, 'linguistic work' produces different paradigms that correspond to the various worlds of different languages. The same thing happens in the articulation and organization of the social continuum in different cultures - think of the systems of family relations analyzed by Lévi-Strauss (Scheffczyk 1998: 1454-1456; see also Ponzio 1997: 191-218; Ponzio et al. 1999: 50-53).

Chomsky's language theory does not keep account of the difference between language and speech. And the theory of the origin of verbal language also tends to ignore this difference. Consequently, Chomsky's language theory attempts to explain the different historical natural languages and their grammars in terms of a hypothetical universal grammar, while the latter searches for the origin of natural languages in another (primordial) natural language. On the contrary, the origin is to be searched for in the human species-specific primary modeling device, in Sebeok's terminology, language, which was a primary adaptation in the evolution of hominids. Speech developed out of language, and like language made its appearance as an adaptation, but for the sake of communication and much later than language, exactly with Homo sapiens, not more than about 300,000 years ago. Only after the physical and neurological capacity for speech evolved in Homo sapiens was speech possible, that is, use of language for vocal communication. Consequently, language too ended up becoming a communication device; and speech developed out of language as a derivative exaptation.

The relation between language and speech, as observes Sebeok, has required a plausible mutual adjustment of the encoding with the decoding capacity. On the one hand, language was 'exapted' for communication (first in the form of speech, i. e., for 'ear and mouth work' and later of script, and so forth), and, on the other, speech was exapted for (secondary) modeling, i.e., for 'mindwork'. 'But', adds Sebeok, 'since absolute mutual comprehension remains a distant goal, the system continues to be fine-tuned and tinkered with still' (Sebeok 1991a: 56). 
But we also find another process of exaptation in the evolution of anthroposemiosis. We are referring to the separation between manual work and intellectual work, which coincides with the separation between 'nonlinguistic' [nonverbal] or 'material' work and 'linguistic [verbal] work', in Rossi-Landi's terminology. The expressions 'linguistic work' and 'nonlinguistic work' are convenient abstractions. However, we should note that they are more than this: they are 'concrete abstractions'. More than just simply convenient expressions for conceptual operations carried out in a theoretical context, they are also aspects of historico-social reality itself. From this second point of view, these two abstractions really exist, they are part of historical reality. Given that verbal linguistic work is functional not only to communication but also to modeling, it presents a fundamental condition with respect to nonlinguistic work. All nonlinguistic work takes place on the basis of the instruments, materials and models of linguistic work. Today's automatic machine represents one of the highest results of exaptation of linguistic work for production and profit, with all the derivative difficulties and contradictions that ensue in social relationships of production.

\section{Machine semiosis and human language}

In their discussion of machine semiosis, Andersen, Hasle, and Brandt (see Andersen et al. 1997) ask what roles may eventually be played by machines in semiosis understood, following the Peircean definition and elaborated by Posner (1997a: 2), as the relationship between interpretant, representamen, and object. The exact question is: we know machines can be objects of signs, but can they be representamens and interpretants? The authors take as their point of departure the homological scheme of production proposed by Rossi-Landi (1975; 1992).

Recognizing humans as the concrete subjects of history, the responsible agents of culture and communicative systems, RossiLandi formulates the thesis of a homology between verbal and nonverbal communication. Linguistic work may be placed on the same level as work that produces physical objects because 'if we do not want to admit that something human can exist for man without the intervention of man himself, we must adhere to the principle that every wealth or value, however understood, is the result of work 
which man has accomplished and can do again' (Rossi-Landi 1983: 35). Since human beings construct themselves historically through the production of tools and verbal messages, Rossi-Landi suggests we render the definition of human beings as speaking and working animals a unitary definition, and consider these two modes of social behaviour as being homologous.

Rossi-Landi's goal was to study the relation between material artifacts and verbal artifacts through a method of analysis referred to as the 'homological method'. This method does not consist in identifying immediate and superficial relations of resemblance, as in analogy, but in identifying homologies, that is, resemblances of a structural and genetic order among objects associated with different fields of knowledge, and which at a superficial glance would seem to be separate. In spite of their different disciplinary provenance and the fact that they appear separate, material and linguistic artifacts may be considered as parts of the same totality because they are the result of human work. Therefore, the homological method has contributed to the critique of hypostatization of parts separated from the totality, to which instead they in fact belong. In so doing this method has also aided discussion about the need to transcend separatism in the sciences.

The homological element breaks with specialization: it obliges one to keep in mind different things at the same time, it disturbs the independent play of separate sub-totalities, and calls for a vaster totality, whose laws are not those of its parts. In other words, the homological method is an antiseparatist and reconstructive method, and, as such, unwelcomed by the specialists. (RossiLandi 1967-1972, 16-17; 1985: 53) ${ }^{1}$

It is obvious that Rossi-Landi's semiotic perspective is holistic or global. Moreover, Rossi-Landi's scheme concerning the structural homology between material and linguistic production does not only use the linguistic notion of the double articulation of language, but also contributes to explaining it. For example, the passage, as described by André Martinet (1960), from the articulation of sentences into words and monemes and these into phonemes turns out to be oriented in the opposite direction from the real process of linguistic production (cf. Rossi-Landi 1992: 173-176). The linguistic work of speakers - both phylogenetically and ontogenetically — proceeds

\footnotetext{
On Rossi-Landi’s homological method, see also Ponzio 1988.
} 
from sounds that are initially disarticulate and gradually become ever more articulate as they form words, phrases and sentences of increasing complexity.

\section{Syntactic articulation and modeling}

The important semiotic concepts of articulation and modeling are closely interrelated and throw light upon each other.

In his homological scheme of production, described in 'Articulations in verbal and objectual sign systems' (in Rossi-Landi 1992: 189-232), Rossi-Landi identifies ten levels in human production. These progress from the zero level of intact, unworked-upon nature, i.e., of material nonsound substance and material sound substance, to the tenth level of global production, i.e., of all objectual sign systems and all verbal sign systems forming a productive unit.

The pieces parked in these five levels, which involve qualitative leaps in the transition from one to the other, are used to build different constructions. The concept of modeling was developed by the Moscow-Tartu school of semiotics in the early 1960s (Lucid 1977; Rudy 1986) to indicate natural verbal language (langue) described as a primary modeling system, while all other human cultural systems were described as secondary modeling systems. However, Sebeok extended the concept of modeling beyond the boundaries of human semiosis relating it to the concept of Umwelt as described by the biologist Jakob von Uexküll (1909). The notion of Umwelt is understood as a model of the external world and has proven crucial for research in disciplines grouped together as 'biosemiotics'. Following such research Sebeok too maintains that probably all life forms are indiscriminately endowed with a modeling capacity. His book of 2000, co-authored with Danesi, The Forms of Meaning, focuses on human modeling processes as distinct from other life forms in the living universe, in particular the world of superior animals.

\section{Machines that interpret}

Let us now return to Rossi-Landi's level 5, the automated machine, and in particular to computer systems. The second question asked by Andersen, Hasle, and Brandt (1997: 549, 552) about machine semiosis 
is the following: 'Should we place machines in the interpreter role?'. The authors' answer is affirmative. This confirms the spontaneous interpretation made in colloquial speech by those who use computers when they anthropomorphize their machines using words like 'ask', 'answer', 'comment', 'know', 'want'.

Finally, the authors deal with the question of whether it is possible to characterize machine-semiosis of semiotic-machines, i.e., of computer-based signs in a relation of contrast with human semiosis. Their reply is negative and is coherent with research on autopoietic systems carried out by the two Chilean biologists, Humberto R. Maturana and Francisco J. Varela (cf. 1980) and their followers, who submit that exactly the same processes obtain in biological organisms. We have already had occasion to mention the autopoiesis theory with regard to the relationship between modeling and dialogue (see A. Ponzio's paper above).

The term autopoiesis was applied to semiosis in 1973 (in a paper entitled 'Autopoiesis and the organization of the living') by Maturana and Varela (see 1980) to name the capacity for self-producing organization unique to living beings. According to this theory, living systems are self-reproductive or autopoietic organizations: these consist of a network of processes that simultaneously produce and materialize that same network as a unity (see also the entry 'Artificial life', Keeley 1998).

The autopoietic organization is defined as a unity by a network of production of components which (i) participate recursively in the same network of productions of components which produced these components, and (ii) participate recursively in the same network of productions as a unity in the space in which the components exist. (Varela et al. 1974: 188)

The theory of autopoietic systems arises from the classical idea of homeostasis, but, as we read in the entry 'Autopoiesis' (Thompson 1998), extends the latter in two significant directions:

First, it makes every reference to homeostasis internal to the very system itself through the mutual interconnection of processes; second, it posits this mutual interconnection as the very source of the system's identity or, in biological terms, of its individuality. (Thompson 1998: 54)

In the light of this theory, according to Andersen et al. (1997: 569), a tentative conclusion of the discussion on the possibility of dis- 
criminating between semiotic machines and human semiosis could run as follows:

[T] he difference between human and machine semiosis may not reside in the particular nature of any one of them. Rather, it may consist in the condition that machine semiosis presupposes human semiosis and the genesis of the former can be explained by the latter. (Andersen et al. 1997: 569)

\section{Automatic machines and human work}

Let us comment on the interpretation, formulated in this article, of the relation between 'semiotic machine', 'computer-based signs', or 'sign machine', on the one hand, and human semiosis, on the other, whose specific characteristic is language, or in Rossi-Landi's terminology, 'linguistic work'.

Subordination of work to the machine is connected with the development of signs (which is discernible in the growth or proliferation of knowledge, competencies, specializations, and sciences). A specific form of subordination is that of linguistic work to the sign machine. In the present age the relation between these two poles is ever more a relation of identification than of homology. Production and communication can no longer be separated while the relation with machines coincides with the relation with signs, verbal and nonverbal. Nor is this simply a case of commodities that are messages and messages that are commodities.

If we follow Rossi-Landi's suggestion and shift from the level of the market to that of linguistic production and sign production in general, we soon realize that automation not only concerns the system of machines but also the system of languages. Reference is to language generally and to historical-natural languages alike, as much as these two different forms of language cannot operate separately from each other. Human work in the communication-production processes of automation developed to the level of the semiotic machine is linguistic work. We have identified a homology between work and its products in the ordinary sense, on the one hand, and linguistic work and its products, on the other (cf. Rossi-Landi 1975; $1985 ; 1992 ; 1994)$. These two faces of a common human capacity for work have now been united in the sign machine as is visible in the relation of inseparability between computer software and computer 
hardware. Indeed, when we speak of linguistic work, reference is to language understood as a specifically human semiotic capacity. Language is a modeling device structural to human beings (cf. Sebeok 1997: 443-444).

Such considerations need to be related to the condition of world or global communication. As indicated by the union which has come about between computer software and hardware, the expression 'global communication-production' - beyond referring to the worldwide extension of the communication phenomenon, that is, over the whole planet - indicates a social system characterized by a new phase in production where machines and signs mutually integrate each other.

In today's phase of development in capitalist production, the machine may replace intellectual work. And this obviously implies that extremely high levels in automation have at last been reached. We are alluding to the fact that automation presents itself in the form of communication, so that in today's technologically advanced world the machine too functions as a sign.

This situation may be analyzed from two different though interconnected viewpoints: the economic and the semiotic. However, in both cases we are dealing with a new event. Regarding the economic aspect, communication is no longer limited to the intermediary phase (exchange) in the social reproductive cycle as in former phases in the development of the capitalist system. On the contrary, communication now identifies with production in the sense that the productive process now presents itself in the form of a communicative process. Furthermore, the third phase in the social reproductive cycle (consumption) also presents itself in terms of communication. In fact, consumption today is above all consumption of communication.

From a semiotic point of view, the development of automation (even in operations which had previously been reserved to intervention by human intelligence) means that communication extends to the field of the artifact, therefore to the field of the artificial and inorganic. This state of affairs does not question the relation of identification between semiosis and life. Indeed, even though communication is now possible in machines, machines continue to be part of the organic world given that they presuppose biosemiosis, and even more specifically anthroposemiosis. The fact is that machines presuppose a certain level in historico-social development in the sphere of anthroposemiosis, and the sphere of anthroposemiosis is the only 
context where machines function as signs. This is exactly what marks the difference between human semiosis and machine semiosis as clarify Andersen et al. (1997: 569).

In any case, automatic development of the machine in terms of 'artificial intelligence' (see Peschl 1998: 44-46) marks the advent of something new in the field of semiosis over the planet Earth. The Authors of the article entitled 'Machine semiosis' are right when they claim that the level of the semiotic machine represents a whole new ladder with respect to preceding levels (cf. Andersen et al. 1997: 551). In the case of traditional automatic machines (i.e., machines that are mechanical and able to replace physical force), communication among machines has always been possible, whether internally or externally with respect to a single piece of machinery. But high levels of development in automation today achieve far more than just a mechanical type of communication relation. It is now possible to achieve in machines as well that type of semiosis we call language, which so far has been described as a species-specific characteristic pertaining to humans.

\section{Machines and metasemiosis}

On the basis of these remarks, the expression 'semiotic machine' is particularly meaningful. Semiotically speaking, we may claim that the machine able to replace human intelligence is not only capable of semiosis but also of semiotics. In this context, as anticipated, by 'semiotics' is understood a metasemiosic process, that is, a process capable of interpreting other semiosic processes, therefore capable of metacommunication. Thus understood semiotics is specific to human beings. And if language is understood in the same terms, we may claim that language, or semiotics, is only possible within the field of anthroposemiosis. Therefore, the automatic machine in a position to replace intellectual work is a machine capable of semiotics - a machine endowed with language.

In this perspective, it is soon obvious that the type of automation we are describing does not merely involve extending semiosis to the inorganic world. In reality, even more significantly that which is extended to the inorganic order is 'semiotics' as we are describing it. Surprisingly enough, then, that which is not possible in any instance of zoosemiosis other than in anthroposemiosis, may instead be 
achieved in the inorganic world. And such a limitation on zoosemiosis incapable of 'semiotics' is as real as the fact that communication is present throughout the entire organic world, indeed is the criterial feature of life itself. However, unlike every other form of organic life beyond the unique exception of human life, the inorganic may be communicative at the highest levels of metasemiosis. This is the most innovative aspect of sign machines, to the point that we may speak of revolution: the inorganic becomes communicative and, what's more, not only in terms of semiosis but also of metasemiosis or semiotics. Consequently, we may now claim that the machine endowed with language is the only case existent of non-organism that is communicative - even more than this, it is the sole non-organism that is not only semiosically but also semiotically communicative. If we consider the biosphere in its entirety in the present age, it will immediately be obvious that not only are human beings endowed with a capacity for metasemiosis, but also the machines that human beings produce.

\section{Interactivity between humans and machines}

At a superficial glance, it may seem that the extremes reached by machine automation thanks to progress in artificial intelligence complete subjection of humanity to the machine, so that machines lose their instrumental character and humans their agency. However, at a closer look, we soon realize that at high degrees of automation this process is inverted. Humans become active subjects once again as they relate to machines that are progressively more intelligent. In fact, as they interact with such machines, human beings recover their function as an indispensable agent in the work process: neither humans nor machines are passive tools, but, on the contrary, are interactive participants in complex processes of exchange (see Böhme-Dürr 1997). Interactivity would seem an apt term to name this relation of exchange. Furthermore, continuous technological development in artificial intelligence calls for the ongoing acquisition of new competencies among the operators of high-powered automatic machines, not only in quantitative terms but also qualitatively.

From a technological perspective, intelligent machines doubtlessly require that human beings continuously update their active response, if they are to equal the new tasks and potential put to them by progress. 
With earlier forms of automation, most typically represented by the assembly line (think of Charlie Chaplin's comico-ironical performance in Modern Times), human intelligence was mortified by the machine's capacity for efficiency. On the contrary, human intelligence today is continuously elicited and challenged for services that are not repetitive but rather require re-elaboration, redefinition and renewal of one's intellectual and practical competencies. Unlike the type of machine unendowed with language, intelligent machines elicit interactivity: active, variable response, innovation, updating, permanent training are all necessary and inevitable even for the sake of mere implementation. The decisive point here is that operators and not only inventors are active. Furthermore, the interactive relation not only concerns the relation between operator and machine, but also between one operator and another. The work process develops through mutual participation, reciprocal assistance, reciprocal exchange of information, data, etc. The functional scheme is neither linear nor circular, indeed the figure that best portrays this new condition is no doubt a grid. Intelligent machines require interactions that develop in networks and, in turn, networks that elicit interactions.

On the subject of the individual's active role in today's social system, Terry Threadgold's observations à propos contributions from the social sciences to semiotics in her article 'Social media of semiosis' are enlightening:

What social labour has asunder is now weaving back together again. It is perhaps interesting just to recall here that all of this also encompasses another significant rewriting, the re-alignment of social and the individual with quite different collocational sets and values. In de Saussure's early formulation, the social was located in the system, the individual outside it. Now, individual action, dialogism, heteroglossia, conflict, institution and society, all those individual and specific things which de Saussure's system excluded, are actually defined as the social, as what constitutes the social and constructs the systematics. The social and the individual are seen as mutually constructive and as constructive of the systems in terms of which they are understood. (Threadgold 1997: 400)

Threadgold clarifies that interaction between the individual and the social should not be understood in terms of opening to alterity, to the outside. In this case, too, what we have is an autopoietic system.

There is no longer any inside and outside, only a constant dialectic between individual and social. The dynamic excluded other (the individual) has 
become the social and the system, and the static, synoptic, social system has now to be accounted for within the terms of that dynamic, as sets of products, codes, whose processes of production have been forgotten, and which maintain only a use-value within this dynamic economy. (Threadgold 1997: 400)

The new type of work that the intelligent machine requires from human beings is assimilated to abstract work, to work in general or indifferent work. Such assimilation is the condition of possibility for the evaluation of work in today's society. In other words, work associated with intelligent machines is quantified according to parameters established by the purchase and sale of work in capitalist society, therefore it is measured in hours.

But the type of work required by the intelligent machine involves specifically human qualities, most notably the capacity for language, semiotic sign behaviour, complex inferential processes capable of innovation and inventiveness. As such this type of work resists standard measurement as employed in today's society: that is, measurement in terms of work time. The type of human work we are describing is incommensurable and unquantifiable. Here human work manifests itself in its constitutive incommensurability, in its essentially qualitative character with respect to which quantity plays a subordinate role; in fact, quantity cannot be the true criterion or norm to account for human work.

In spite of its incommensurability as the source of all historicosocial value, human work has been assimilated to quantified abstract work measured in hours. As such it has been reduced to the status of commodities, which is the condition for the very constitution of capitalist society. This same operation has already been applied to linguistic work as well, to the point that we may speak of 'linguistic alienation' (cf. Rossi-Landi 1983; 1992). However, never before has capitalist profit depended so heavily on the reduction of linguistic work to the status of commodities, as in the current phase in capitalist production (which may be described as the 'communication-production' phase: see Ponzio 1999; Ponzio, Petrilli 2000). It is paradigmatic that, as Anderson et al. (1997: 551) note, software (sign complexes) now defines the 'machine' while hardware (the physical machine) plays a subordinate role. This fact represents a fundamental change in the human production of artifacts. Such expressions as 'immaterial investment' or 'appreciation of human resources' or 'human capital' are symptomatic of today's subordination of produc- 
tion to linguistic work. At the same time, however, the authors mentioned also refer to the employment of linguistic work, therefore of intelligence, the mind, the human brain as inexorable resources in the present day and age for the development of companies and their competitiveness.

All this implies that in today's world human individuals distinguish themselves thanks to their capacity for metasemiosis, i.e., for language, the source of value, while work continues to be considered in terms of commodities and evaluated in such terms. Consequently, never before has there emerged in human work so sharp a contrast between the inherent capacity to increase its value and its status as a commodity. While human work as such is manifestly incommensurable, today more than ever it is treated as just another piece of merchandise. The contradiction between linguistic work and the work market is intensified in a manner similar to the contradiction between the inherent unquantifiability of human work and the systematic demand to commodify (thus, to quantify) the worker's economic contribution to capitalist production. Such a contradiction in this specific system exalts the quality of work in the form of linguistic work to a maximum degree and is specific to what we have identified as communication-production society. This new contradiction between linguistic work and the work market ensues from the relationship between work in the contemporary world and semiotic machines.

\section{Semiotics, significs and ethics}

As we have claimed elsewhere against a reductive interpretation of Peircean semiotics (see Petrilli 1997; 1999a; Sebeok et al. 2001: 73135), the problem of the relation to others, of dialogue and ethical responsibility are no less than pivotal in Peirce's conception of the human subject. An aspect of Peirce's sign theory that should not be underestimated is its contribution towards a redefinition of the subject. In a Peircean perspective the human being, the self, viewed as a sign, coincides with the verbal and nonverbal language it is made of, with thought. The subject comes into being as a semiosic process with the capacity to engender a potentially infinite number of signifying trajectories in the dynamics of the relationship between utterance and interpretation. As says Peirce, 'men and words reciprocally educate each other; each increase of a man's information involves and is 
involved by, a corresponding increase of a word's information' ( $C P$ 5.313). Insofar as it is a sign, that is, a sign in becoming, the subject emerges as a dialogic and relational open unit, an ongoing process evolving in the intrapersonal and interpersonal dialogic interrelationship with other subjects. The dialogic conception of thought and subjectivity as developed throughout the course of his research may be traced back to Peirce's early writings. Insofar as it is a sign, the subject's boundaries are not defined once and for all and can only be delimited in the dialogic encounter with other subjects. The human person is born into a community where experiences are lived in relation to the experiences of the other members of that community and never isolatedly from it.

[W]e know that man is not whole as long as he is single, that he is essentially a possible member of society. Especially, one man's experience is nothing, if it stands alone. If he sees what others cannot, we call it hallucination. It is not 'my' experience, but 'our' experience that has to be thought of; and this 'us' has indefinite possibilities. (CP 5.402, n.2)

As regards the ethic and social implications of semiotic inquiry, another eminent student of signs in addition to Peirce, Bakhtin, and Morris (see especially The Open Self, Varieties of Human Value, and Signification and Significance), is Victoria Lady Welby (see Petrilli 1998a; Sebeok 2001: 146-148). An article on 'Significs' (Schmitz 1998), the name of the semiotico-philosophical trend founded by Welby, is included in Semiotik/Semiotics, but it reserves too small a space for such an important scholar while rightly highlighting the Signific Movement in the Netherlands, which originated from Welby's research through the mediation of Frederik van Eeden.

Welby's significs transcends pure descriptivism in the effort to analyze signs in their ethical, esthetic and pragmatic dimensions beyond the epistemological and cognitive boundaries of semiotics, where semiotics and axiology intersect. Welby's proposal of significs arises from the assumption that the problem of sign and meaning cannot be dealt with separately from consideration of the place and value of meaning in all possible spheres of human interest and purpose. Her project pushes beyond the limits of semiotics understood as 'cognitive semiotics' as much as beyond the specialism of semantics. Being concerned with problems of meaning in everyday life and not just in relation to specialized sectors, significs invites us all, not just the specialist but each one of us in daily life, to ask the 
question 'What does it signify?', which is not intended to interrogate linguistic meaning alone but also the value something has for us. Consequently, significs emerges as a method in mental exercise with implications of an ethic and pedagogic order, relevant to interpersonal and social relationships and therefore to making responsible choices.

Other expressions used by Welby to designate her theory of sign and meaning, or significs, is 'philosophy of significance' and 'philosophy of translation', which highlight different aspects of her approach. The significance of signs increases with the increase in translative processes across different types and orders of signs. In fact, translation as described by Welby is a method of interpretation and comprehension and as such is pioneeristically conducted into the territory of reflection on signs and meaning. In this context translation is not understood solely in interlingual terms, though it is this too, but even more significantly as intersemiotic and intralingual translation, to use Jakobson's terminology. All signs and expressions are already translations in themselves, as confirmed by Peirce's concept of sign. Mental activities, as Welby maintains - once again in accordance with Peirce - are automatic translative processes. Welby's theory of translation is structural to her significs and is closely connected with her reflections on the figurative nature of language, therefore on the role carried out by metaphor, analogy, and homology in the development of thought, knowledge and communication processes. Thanks to such an approach significs also emerges as a method for the enhancement of awareness, for augmenting and mastering translative processes as the condition for understanding the sense, meaning and significance of verbal and nonverbal behaviour at large. As such Welby's significs concerns the ethic dimension of sign life and its study beyond the strictly cognitive or epistemological dimension.

\section{Listening and the vocation of semiotics for the health of life}

In the first and second volumes of Semiotik/Semiotics music is treated a topic in the study of signs, and is analyzed in different cultures and successive eras in Western history: sign conceptions in music in Ancient Greece and Rome (Riethmüller 1997), in the Latin Middle Ages (Gallo 1997), from the Renaissance to the early 19th century (Baroni 1998), from the 19th century to the present (Tarasti 1998). 
Moreover, in the third volume (Posner et al. 2003) discussion of the relationship between semiotics and the individual disciplines (Chapter IX) also includes an article (Mazzola 2003) on semiotics of music. As in the case of other disciplines, discussion concerning music and musicology also focuses on the epistemologically relevant question concerning the extent to which the subject matter, methods, and forms of presentation in this discipline may be understood as sign process. But we must observe that music is not just another subject among many others in semiotics. Music is a special subject.

With respect to semiotics and the other sciences of language, music has proven to be a very difficult topic to deal with if treated in the light of the verbal language paradigm. Of the various languages music more than any other resists the phonocentric approach to semiosis. Semiotics of music must answer the question: 'which semiotics for semiotics of music?'. On referring to music, semiotics must be ready to interrogate its own categories and methods. Music may be understood as a sign process on the condition that semiotics is 'semiotics of music'. Here 'of music' is understood as a subject genitive, i.e., 'semiotics of music' not in the sense of semiotics applied to music, but semiotics as a perspective belonging to music, semiotics as proposed by music. Since music is inconceivable without the attitude of listening, semiotics of music is semiotics also in the sense of general semiotics understood as semiotics of listening. Instead of interrogating the different and various types of signs on the basis of preexisting categories, semiotics thus described is first of all listening. Global semiotics is global not only in terms of extension, but first and foremost because of its capacity for listening (on these aspects of general semiotics and semiotics of music, see Ponzio 1993: 138-154; Lomuto, Ponzio 1997).

Listening evokes auscultation, a medical posture. In Ancient Greece music was thought to be therapeutic. On the other hand, it seems that semiotics originated from semeiotics, classified by Galen as one of the principal branches of medicine (on sign conceptions in medicine in Ancient Greece, see Langhoff 1997; on the medical origin of semiotics, see Sebeok 1994: 50-54; on Galen in medical semiotics, see Sebeok 2001: 44-58). Besides auscultation and other ways of inspecting symptoms, diagnosis and anamnesis, following Galen, include listening to the patient who is invited to talk about his ailments and to tell the story of his troubles. 
Medicine today, as denounced by Michel Foucault, is functional to exercising what he calls 'bio-power', to promoting the techniques of subordination of the body to the knowledge-power of biopolitics. Medicine contributes to the controlled insertion of bodies into the production cycle. With its specialisms and manipulation of bodies as self-sufficient entities, medicine strengthens the dominant conception of the individual as belonging to spheres of interest that are separate from each other and as having needs that are indifferent to each other. In such a context listening becomes 'direct, univocal listening', imposed by the Law (Barthes, Havas 1977: 989), by the 'order of discourse' (Foucault 1970), it becomes 'applied listening', 'wanting to hear', imposition to speak and, therefore, to say univocally. Listening is one thing, to want to hear is another. Listening is answering comprehension: 'listening speaks', says Barthes (Barthes, Havas 1977: 990) similarly to Bakhtin; listening is turned to signs in their constitutive dialogism. By excluding responsive listening, the will to hear or applied listening belongs to a 'closed universe of discourse' (Marcuse), which fixes interrogation and responsive roles and separates listening from answering comprehension. Unlike listening understood as dialogue and answering comprehension which continuously produces new signifiers and interpretants without ever fixing sense, 'applied' listening takes place in a rigid network of speech roles: it maintains the 'ancient places of the believer, the disciple, the patient' (Barthes, Havas 1977: 990).

The attitude of listening is decisive for the task of global semiotics, for the capacity to understand the entire semiosic universe as well as to discuss the different forms of separatism and the different tendencies to take the part for the whole, whether by mistake or in bad faith. This is the case of individualism in social and intercultural life as well as of the current 'crisis of overspecialization' (Posner et al. 1997: xxix) in scientific research.

The capacity of semiotics for listening is an effective condition for reconnecting semiotics to its early vocation and expression as medical semeiotics, as described especially by Sebeok. If semiotics is interested in life over the whole planet since life and semiosis coincide (however, for a critical discussion of the equation between 'the concepts of life process and sign process', see Kull 2002), and if the original motivation for the study of signs is 'health', we may claim that a non negligible task of semiotics, especially today in the era of globalization, is to care for the whole of life in its globality. 


\section{Semiotics and responsibility: semioethics}

With the spread of "bio-power" and the controled insertion of bodies into the production system, world communication goes hand in hand with the spread of the idea of the individual as a separate and selfsufficient entity. As anticipated at the beginning of this paper, the body is experienced as an isolated biological entity, as belonging to the individual, as part of the individual's sphere of belonging which has led to the almost total extinction of cultural practices and worldviews based on intercorporeity, interdependency, exposition and opening. We have already compared the private and static conception of the body in today' system of global production-communication with 'grotesque realism' in medieval popular culture, as theorized by Bakhtin (1965) for example.

As Foucault in particular has revealed (but let us also remember Rossi-Landi's acute perception of the situation as formulated in his books of the 1970s), division and separatism among the sciences are functional to the ideologico-social necessities of the "new canon of the individualized body' (Bakhtin). This in turn is functional to the controled insertion of bodies into the reproduction cycle of today's production system.

A global and detotalizing approach to semiotics demands opening to the other and the extreme capacity for listening to the other, therefore, it involves the capacity for a dialogic relationship with the other. Accordingly, we propose an approach to semiotics that privileges the tendency towards detotalization rather than totalization. Otherness opens the totality to infinity or to 'infinite semiosis' which leads beyond the cognitive order or the symbolic order to enter the ethic dimension, opening to the condition of infinite involvement and participation with the other, of responsibility towards the other.

Such considerations orient semiotics according to a plan that is not the expression of a specific ideology. On the contrary, semiotics thus described concerns behaviour ensuing from awareness of the radical nature of human responsibility as a 'semiotic animal'. Properly understood, the 'semiotic animal' is a responsible actor capable of signs of signs, of mediation, reflection and awareness in relation to semiosis over the entire planet. In this sense global semiotics must be adequately founded in cognitive semiotics, but it must also be open to a third dimension beyond the quantitative and the theoretical, that is, the ethical. Since this third dimension concerns the ends towards 
which we must strive and which we aim to reach, we propose to characterize it as 'semioethics' (see Ponzio and Petrilli 2003).

For semiotics to meet its commitment to the 'health of semiosis' as well as to cultivate its capacity to understand the entire semiosic universe, it must continuously refine its auditory and critical functions, its capacity for listening and criticism. And to accomplish such tasks we believe the trichotomy that distinguishes between (1) cognitive semiotics, (2) global semiotics, and (3) semioethics is important, indeed decisive not only theoretically but also for therapeutic reasons.

\section{Subjectivity and alterity}

The categories of 'identity' and 'subjectivity' are intimately interconnected and perform a decisive role in world-wide and global communication, whether a question of the identity of the individual or of the collective subject (Western world, European Union, nation, ethnic group, social class, etc.).

The concepts of individual and community identity alike call for analysis in a semiotic key. And identity in either form may either be governed by a monologic or by a dialogic. The difference is profound and pervasive.

Peirce's reflections have contributed significantly to a redefinition of the subject (Petrilli and Ponzio 2002; see also Colapietro 1989; Petrilli 1999b; Sebeok et al. 2001). The human being, the I, is a sign of an extraordinarily complex order, made of verbal and nonverbal language: 'It is that the word or sign which man uses is the man himself [...] the man and the external sign are identical, in the same sense in which the words homo and man are identical' (CP 5.314). Consequently, the subject may be described as a semiosic process, indeed thanks to its interpretive-propositional commitment, the subject consists of a potentially infinite number of signifying trajectories.

As a developing sign, the subject is a dialogic and relational entity, an open subject emerging in the intrapersonal and interpersonal interrelationship with other subjects. Therefore, the boundaries of the subject-sign are not defined once and for all, but can only be defined in and through dialogic encounters with other with other subjects.

The human person develops in sociality, relatedly to the experiences of others and never in isolation. Indeed, the self, the subject is a community structured to obey the laws of the logic of otherness. The 
self is a community of dialogically interrelated selves. If we interpret the word 'in-dividual' literally as meaning 'non divided, non divisible', with Peirce we may claim that 'a person is not absolutely an individual' ( $C P$ 5.314). Peirce rejected the 'illusory phenomenon' of a finite self or a self-sufficient self.

The social and communal character of self does not contrast with its singularity and uniqueness or with its signifying otherness with respect to any interpretive process that may concern it. The self is ineffable (cf. $C P$ 1.357), it is saying beyond the said; the utterances of self convey significance beyond words. At the same time, however, the ineffability and uniqueness of self do not imply incommunicability.

The identity of the subject is multiplex, plurifaceted and plurivocal, it is delineated and modeled in the dialogic relation among its various parts. Welby establishes a distinction between the I and the Self as we learn from her unpublished manuscripts, which include a file entitled Subjectivity with texts written between 1903 and 1910 (Welby Collection, York University Archives, Toronto, cf. Petrilli 1998a for a description of the materials available at the archives). In the papers included in this file, especially those written between 1907 and 1910, she analyzes the problem of subjectivity in terms of the complex and articulated relation between what she calls the 'I', or, introducing a neologism Ident, and the 'self'. The self, also designated with the neologism ephemeron, is mortal, ephemeral like the body. By contrast, the I tends towards immortality beyond the mortality of the body and of the self. Formed in this way, identity is not unitary or compact, but on the contrary presents a surplus, something more with respect to identity itself. Identity is constructed in the dialogic relationship of the self with the I. Welby's conception of identity recalls Peirce's as we have already discussed it. I or Ident is not the 'individual' but the 'unique'. Indeed, 'It is precisely our di-viduality that forms the wealth of our gifts', as says Welby in the unpublished papers we are interpreting.

That the subject is inevitably an incarnate subject, thus intercorporeal being, that is to say, a body connected to other bodies from the very outset, an expression of the condition of intercorporeity on both the synchronic and diachronic levels for the whole of its subsequent life, that the subject is not incarnated in a body isolated from other bodies is not indifferent to our conception of the person. The subject is an incarnate entity from the point of view of biological 
evolution, of the species, as well as of sociality and cultural history. The body plays a fundamental role in the development of awareness or consciousness: consciousness is incarnate consciousness. The body is a condition for the full development of consciousness, of the human being as a semiotic animal. The self develops interrelatedly with other bodies through which it extends its boundaries, therefore the boundaries of the world it experiences. The word is an extension of the body. Indeed, echoing Bakhtin, we may claim that the word forms a bridge joining one's own body to the body of others. Peirce makes recurrent use of the expression 'flesh and blood' (cf. CP 1.337, 7.591) for the physiological body which can only be distinguished from the semiotic body by abstraction similarly to the distinction between physical, extrasign and instrumental materiality, on the one hand, and sign material which ultimately has a physical referent, on the other, even though it may not be immediately obvious as in the case of dreaming or silent thinking (see Petrilli 1986 and 1998b, new ed.: 3848, and 146-147).

Given its broad scope, semiotics must keep account of and account for the 'reason of things'. However, the capacity for detotalization as the condition for critical and dialogic totalization implies that the ability to grasp the reason of things cannot be separated from the capacity for reasonableness. The issue at stake may be stated in the following terms: given the risks inherent in the current phase in historical development for semiosis and for life, human beings must at their very earliest change from rational animals into reasonable animals.

Both Welby and Peirce have contributed to the development of a truly global science of signs capable of accounting for signifying processes in all their complexity and articulation, of considering meaning not only in terms of signification, but also of sense and significance. For Peirce and Welby alike, study of the life of signs and of the signs of life cannot be conducted in merely descriptive terms, that is to say, with claims to neutrality. If Welby coined the term 'significs' her aim was to indicate a sign theory that is comprehensive and critical, one squarely confronting the problem of the relation of signs and values. The term 'significs' designates the disposition for evaluation and, therefore, the value conferred upon signs, their pertinence, scope, signifying value, significance. 
In Welby's view, hedonist ethics, the dominant ideology of her time (similarly to the present era), reduces the vast multiform cosmos to the status of mere annex of the planetary egoist and parasite.

It is significant that Peirce too should have turned his attention specifically to the normative sciences in the final phase of his research. He linked logic to ethics and esthetics: while logic is the normative science concerned with self-controled thought, ethics focuses on self-controled conduct, and esthetics is devoted to ascertaining the end most worthy of our espousal. In this context, Peirce took up the question of the ultimate good, summum bonum, or ultimate value, which he refused to identify with either individual pleasure (hedonism) or with societal good such as the greatest happiness for the greatest number of human beings (English utilitarianism). On the contrary, he insisted that the summum bonum could only be defined in relation to the 'evolutionary process', that is, to a process of growth. Specifically, he identified the highest good in the continuous 'growth of concrete reasonableness'.

The dialogic relation between self and other (the other from self and the other of self) emerges as one of the most important conditions for continuity in the creative process. A driving force in this creative process is love in the sense of agape. According to Peirce, the most advanced developments in reason and knowledge are based on the creative power of reasonableness and the transformative suasions of agape.

Thus conceived, reasonableness is endowed with the power of transforming one's horror of the stranger, the alien, one's fear of the other understood as the fear one experiences of the other foreign to oneself, into sympathy for the other become lovely. Developing Peirce's discourse in the direction of Levinas's philosophy of subjectivity, we might add that under the hardened crust of its identity the subject rediscovers its fear for the other through love, for the other's safety, a fear that renders one incessantly restless and preoccupied for the other. Love, reasonableness, creativity are all grounded in the logic of otherness and dialogism, and together they move the evolutionary dynamics of consciousness.

While working on pragmaticism with reference to the problem of subjectivity, the self considered as a set of actions, practices, habits, Peirce identified 'power' as opposed to 'force' as a fundamental characteristic of the self. He describes the self as a center oriented towards an end, an agent devoted to a more or less integrated set of 
'purposes'. This may be related to what Welby understood with the terms 'purport' or 'ultimate value' when she described sense as the signifying value designated by the third element of her meaning triad, that is to say, 'significance'. Power is not 'brute force' but the 'creative power of reasonableness', which, by virtue of its agapastic orientation rules over all other forms of power (cf. CP 5.520). We may claim that power, that is, the ideal of reasonableness, is the capacity to respond to the attraction exerted upon self by the other; power and reasonableness are related to the capacity for response to the other and the modality of such response is dialogue.

The relationship between self's humility and fragility, on the one side, and the risks implied in self's readiness to venture towards that which is other, on the other side, has already been portrayed by Plato in his myth about Eros (in the Symposium), a sort of intermediate divinity or demon generated by Penia (poverty, need) and Poros (the God of ingenuity), who is capable of finding the way even when it is hidden. With reference to the human world, Welby described the connection between self enrichment and risky opening towards others as a condition for evolution. Such connection engenders an orientation which may be described in terms of the critique of 'being satisfied', that is, in terms of 'transcendence' with respect to reality as it is, with respect to ontological being given and determined once and for all: 'We all tend now, men and women, to be satisfied [...] with things as they are. But we have all entered the world precisely to be dissatisfied with it', says Welby in the unpublished manuscripts on Subjectivity cited above. 'Dissatisfaction' is an important ingredient for the concept of 'mother sense' and signals the need to recover the critical instance of the human intellectual capacity. So beyond the cognitive capacity, it should now be obvious that we are alluding here, in the first place, to the capacity for otherness, to the structural capacity for creativity and innovation, for shifting and displacing sense. And thanks especially to the procedures of abductive logic this critical instance allows for prevision and 'translation' in the broadest sense possible, understood, that is, as interpretation and verification of verbal and nonverbal signs beyond the limits of interlingual translation.

It is significant for our discussion that Welby, in a letter of January 21st. 1909, agreed with Peirce's observation that logic is the 'ethics of the intellect', which she related to a concept central to her own theory - 'primal' or 'mother-sense': 'Of course I assent to your 
definition of a logical inference, and agree that Logic is in fact an application of morality in the largest and highest sense of the word. That is entirely consonant with the witness of Primal Sense' (in Hardwick 1977: 91). Scientific rigor in reasoning results from agapastic logical procedures, from 'primal sense', therefore from the courage of admitting to the structural necessity - for the evolution of sign, subject and consciousness — of inexactitude, instability and crisis.

\section{Humanism of human signs}

In the light of what has been said so far, semioethics may be considered as proposing a new form of humanism. In fact, semioethics is committed at a pragmatic level, furthermore it is capable of transcending separatism among the sciences relating the natural sciences and the logico-mathematical sciences to the historico-social or human science, and again it evidences interconnectedness between the problem of humanism and the question of alterity.

This new form of humanism cannot but be the humanism of alterity, a point convincingly demonstrated by Levinas throughout his writings and especially in Humanisme de l'autre homme (1972). The claim to human rights centered on identity, the approach to human rights to have dominated thus far, has left out from the very concept of 'human rights' the rights of the other. This approach must quickly be counteracted by the humanism of alterity where the rights of the other are the first to be recognized. And our allusion here is not just to the rights of the other beyond self, but also to the self's very own other, to the other of self. Indeed, the self characteristically removes, suffocates, and segregates otherness mostly sacrificed to the cause of identity. But identity thus achieved is fictitious, so that all our efforts invested in maintaining or recovering identity thus understood are destined to fail.

Semiotics contributes to the humanism of alterity by bringing to light the extension and consistency of the sign network that connects each human being to every other. This is true both on a synchronic and a diachronic level: the world-wide spread of communication actually means that a communication system is progressively being established on a planetary level and as such is a phenomenon susceptible to synchronic analysis; and given that the human species is implied in all events, behaviours, individual decisions, in the overall destiny of the 
individual from its most remote to its most recent and closest manifestations, in its past and in its evolutionary future, on a biological level and on a historico-social level, diachronic investigations, to say the least staggering for diversity, are necessary. The sign network we are describing concerns the semiosphere as constructed by humankind, a sphere inclusive of culture, its signs, symbols, artifacts, etc.; but global semiotics teaches us that this semiosphere is part of a far broader semiosphere, the semiobiosphere, forming the habitat of humanity (the matrix whence we sprang and the stage on which we are destined to act).

Semiotics has the merit of having demonstrated that whatever is human involves signs. Indeed, it implies more than this: whatever is simply alive involves signs. And this is as far as cognitive semiotics and global semiotics reach. But semioethics pushes this awareness further in the direction of ethics and even beyond ethics; for semioethics makes the question of responsibility inescapable at the most radical level (that of defining commitments and values). Our ethos, but more than this, the cosmos itself falls within the scope of our responsibility. Among other things, this means that we must interpret humanity's sign behaviour in the light of the hypothesis that if all the human involves signs, all signs are human. This humanistic commitment, however, does not mean to reassert humanity's (monologic) identity yet again, nor to propose yet another form of anthropocentrism. On the contrary, what is implied is a radical operation of decentralization, nothing less than a Copernican revolution. As Welby would say, 'geocentrism' must be superceded, then 'heliocentrism' itself, until we approximate a truly cosmic perspective. The attainment or approximation of such a perspective is an integral part of our ultimate end, hence a point where global and 'teleo-' or 'telosemiotics' or, as we now propose, 'semioethics' intersect. As already observed, otherness more than anything else is at stake in the question of human responsibility and therefore of humanism as we are now describing it. But the sense of alterity here is other than what has previously been acknowledged: it is not only a question of our neighbour's otherness or even of another person at a great distance from us, in truth now recognized as being extremely close, but also of living beings most distant from us on a genetic level.

Reformulating a famous saying by Terence (homo sum: humani nihil a me alienum puto), Roman Jakobson (1963) asserts that: linguista sum: linguistici nihil a me alienum puto. This commitment 
on the part of the semiotician to all that is linguistic, indeed, endowed with sign value (not only relatively to anthroposemiosis nor just to zoosemiosis, but to the whole semiobiosphere) should not only be understood in a cognitive sense but also ethically. Such a commitment involves concern not only in the sense of 'being concerned with...', but also of 'being concerned for...', 'taking care of...'. Viewed in this perspective, concern, care, responsibility, unlimited by belonging, proximity, community, communion, is not even that of the 'linguist' nor of the 'semiotician'. Modifying Jakobson's claim, we may state that it is not as professional linguists or semioticians that we may not consider anything that is a sign as a me alienum, but rather (leaving the first part of Terence's saying unchanged) we could claim that homo sum, and, therefore, as humans we are not only semiosic animals (like all other animals), but also semiotic animals and in this sense we are unique. Consequently, nothing semiosic, including the biosphere and the evolutionary cosmos whence it sprang, a me alienum puto.

Semioethics does not have a program to propose with intended aims and practices, nor a decalogue, nor a formula to apply more or less sincerely, therefore, more or less hypocritically. From this point of view, semioethics contrasts with stereotypes as much as with norms and ideology. On the contrary, semioethics proposes a critique of stereotypes, norms and ideology, of the different types of value characterized, for example, by Morris in Signification and Significance, 1964 (above all, his tripartition of values into operative, conceived, and object values, along with the subordinate distinctions of the dimensions of value into detachment, dominance, and dependence). Semioethics is the capacity for critique and its special vocation is to make manifest sign networks where it seemed there were none, bringing to light and evaluating interconnections, implications, involvement, contact which cannot be evaded, where it seemed there were only net separations, boundaries and distances with relative alibis. These serve to safeguard responsibility in a limited sense, therefore consciousness, which in fact very easily presents itself as a 'clear conscience'. The component 'telos' in the expression 'teleo-' or 'telosemiotics', terms we also propose for this particular orientation in semiotics, does not indicate some external value or pre-established end, an ultimate end, a summum bonum outside the sign network. Rather it indicates the telos of semiosis itself understood as an orientation beyond the totality, beyond the closure of totality, 
transcendence with respect to a given entity, a given being, infinite semiosis, movement towards infinity, desire of the other. And, indeed, in the present context one of the special tasks of semioethics is to expose the illusoriness of the claim to the status of differences that are indifferent to each other (cf. Ponzio 1994).

\section{Bioethics and semioethics}

Problems relevant to bioethics must be appropriately contextualized if they are to be treated adequately. Global semiotics provides contextualization of the phenomenological and ontological orders, but we must also consider today's socio-economic context, that is, the context of global communication-production (see Petrilli, Ponzio 2002: III.1.1). These contexts are closely interrelated from the perspective of ethics.

In fact, if we consider the contribution made by global semiotics to bioethics from the point of view of global communication-production today, semiotics must clearly face an enormous responsibility, that of evidencing the limits of communication-production society. Semiotics must now accept the responsibility of denouncing incongruities in the global system with the same energy, instruments and social possibilities produced by the global communication-production system itself. Semioticians must now be ready to denounce the dangers inherent in this system for life over the entire planet.

The current phase in the development of the capitalist system has been indicated as 'global communication'. This expression may be understood in at least two different ways: (1) that communication is now characterized by its extension over the whole planet; and (2) that it accommodates itself realistically to the world as it is. Globalization implies that communication is omnipresent in production and characterizes the entire social reproductive cycle: not only is communication present at the level of the market, of exchange, as in earlier phases in socio-economic development, but also at the level of production and consumption. Globalization is tantamount to heavy interference by communication-production not only in human life, but in life in general over the whole planet.

An adequate understanding of world-wide global communicationproduction calls for an approach that is just as global. While the special sciences taken separately are not in a position to provide such 
a global view, the general science of signs or semiotics as it is taking shape today on the international scene is, thanks especially to Sebeok and his ongoing research.

A full understanding of global communication today implies a full understanding of the risks involved by global communication, including the risk that communication may come to an end. However, this risk does not simply refer to the phenomenon known as 'incommunicability', a subjective-individualistic ailment which emerged in the transition to communication in its current forms (and no longer separable from production). More than this, if it is true that communication and life converge, the risk that communication may end is nothing less than the risk that life itself on the planet Earth may come to an end, considering today's enormous potential for destruction by comparison with earlier phases in the development of the social system.

Therefore, the expression 'global communication-production' does not only refer to the expansion of the communication network and of the market supporting it at a world-wide level, but also to the fact that the whole of human life is englobed by the communication-production system: whether in the form of development, well-being and consumerism or of underdevelopment, poverty and impossibility to survive; health or sickness; normality or deviation; integration or emargination; employment or unemployment; transfer functional to the work-force characteristic of emigration or transfer of peoples characteristic of migration as their request for hospitality is denied; the traffic and use of legal commodities or of illegal goods, from drugs to human organs, to 'non-conventional' weapons. Indeed, this process of englobement is not limited to human life alone. All of life over the entire planet is now inexorably implied (even compromised and put at risk) in today's communication-production system (cf. Petrilli, Ponzio 2002: III, II.1.1).

Reflection on problems relevant to bioethics today keeping account of the context they belong to, that of globalization, requires an approach that is just as global. An approach that does not simply consider partial and sectorial aspects of the communication-production system according to internal perspectives functional to the system itself; an approach that is not limited on an empirical level to psychological subjects, to subjects reduced to the parameters imposed by the social sciences, that is, measurable in terms of statistics. Global communication-production calls for a methodological and theoretical 
perspective that is just as global as the phenomenon under observation, a perspective capable of understanding the logic of global communication-production and of proceeding therefore to an adequate critique.

Analysis of today's world of global communication in all its complexity calls for conceptual instruments that must be as precise as possible. These can only be furnished by a new theory of communication. Such conceptual instruments must also be as rigorous as possible and this can only be furnished by their philosophical grounding. An attempt in this sense has been made by Ponzio in the volume, La comunicazione (1999) and in another volume co-authored with Petrilli, Il sentire nella comunicazione globale (2000).

Social reproduction in the global communication-production system is destructive. Reproduction of the productive cycle itself is destructive. It destroys: (a) machines, which are continuously replaced with new machines - not because of wear but for reasons connected with competitivity; (b) jobs, making way for automation which leads to an increase in unemployment; (c) products on the market where new forms of consumerism are elicited, ruled completely by the logic of reproducing the productive cycle; (d) previous products which once purchased would otherwise exhaust the demand and which in any case are designed to become immediately outdated and obsolete as new and similar products are continuously introduced on the market; (e) commodities and markets unable to resist competition any longer in the context of the global communication-production system.

The conatus essendi of communication-production destroys natural environments and life forms. It also destroys different types of economic systems and diversity in culture tending to be eliminated by the processes of homologation operated by market logic. These days not only are habits of behaviour and needs rendered identical (though the possibility of satisfying such needs is never identical), but even desires and the imaginary tend to be homologated. The conatus essendi of communication-production also tends to destroy traditions and cultural patrimonies that contrast with or obstacle or are simply useless or nonfunctional to the logic of development, productivity and competition. The conatus essendi of communication-production tends to the destruction of those productive forces that escape the logic of production penalizing intelligence, inventiveness and creativity, which are over-ruled by or subjected to 'market reason' (which cannot be avoided when production must necessarily invest in 'human re- 
sources'). The destructive character of today's production system is also manifest in the fact that it produces growing areas of underdevelopment as the very condition for development, areas of human exploitation and misery to the point of nonsurvival. Such logic subtends the expanding phenomenon of migration which so-called 'developed' countries are no longer able to contain due to objective internal space limitations - no doubt greater than in earlier forms and phases in the development of the social system.

Universalization of the market, that is, the application of the status of commodities to all things and relationships is destructive; and the more so-called commodities are illegal and prohibited - think of drugs, human organs, children, uteruses, etc. - the more they are expensive. The principle of exploiting other people's work is destructive. Work obviously costs less the more it produces profit: with the help of global communication developed countries are more and more turning to low cost work in underdeveloped countries. The disgrace of the communication-production world is particularly manifest in the spreading exploitation of child labour that is heavy and even dangerous (much needs to be said and done about children as today's victims of underdevelopment, in misery, sickness, war, on the streets, in the work-force, on the market...).

The destructive character of world-wide communication-production is also evidenced by war, which is always a scandal. Global communication-production is the communication-production of war. War requires new and flourishing markets for the communicationproduction of conventional and unconventional weapons. War also requires widespread approval acknowledging it as just and necessary, as a necessary means of defence against the growing danger of the menacing 'other': therefore, war as a means of achieving respect for the rights of 'one's identity', 'one's difference'. The truth is that identities and differences are neither threatened nor destroyed by the 'other'. The real menace is today's social system that encourages and promotes identity and difference while rendering them fictitious and phantasmal. And this is precisely one of the reasons why we cling to such values so passionately, being a type of logic that fits the communication-production of war to perfection.

The technologies of separation as applied to human bodies, to interests, to the life of individual and collective subjects are functional to production and to identifying production with consumption characteristic of today's production system. With respect to all this and 
thanks to its ontological perspective, global semiotics (or semiotics of life) if nothing else can oppose a whole series of signs showing how each instant of individual life is wholly interrelated, even compromised with all other forms of life over the entire planet.

To acknowledge such interconnectedness, such compromise involves a form of responsibility that far exceeds all positive rights and all limited responsibilities, restricted responsibilities with alibis. Such awareness is ever more urgent the more the reasons of production and of global communication functional to it impose ecological conditions that impede and distort communication between our bodies and the environment.

An ontological reformulation of bioethics on the basis of semiotics of life with reference to today's socio-economic context as delineated by global communication helps identify two fundamental principles for the human being: dispossession and extralocalization. These principles allude to the human individual as a living body interconnected with all other forms of life over the planet thanks to the condition of diachronic and synchronic intercorporeity. The human body is dispossessed with respect to techniques that encourage and favour subordination to the knowledge-power of biopolitics (Foucault); and extralocalized with respect to chronotopic coordinates, projects, structures and roles functional to reproduction in the economico-social form of global communication.

The principles of dispossession and extralocalization are manifest in the body's tendency to 'escape without rest' from techniques that, on the contrary, aim to dominate and control it; the body's 'persistence in dying'. Dispossession and extralocalization are principles that must be taken into account for the prolegomena of an approach to bioethics that is critical, philosophical and theoretical the very condition for recognizing nothing less than the moral and juridical status of such principles.

\section{References}

Andersen, Peter Bøgh; Hasle, Per; Brandt, Per Aage 1997. Machine semiosis. In: Posner et al. 1997: 548-571.

Bakhtin, Mikhail M. 1963. Problemy poetiki Dostoevskogo. Moscow: Sovetskij pisatel. [Eng. trans. Problems of Dostoevsky's Poetics. Emerson, Caryl (ed.). Minneapolis: University of Minnesota Press, 1984.] 
- 1965. Tvorchestvo Fransua Rable. Moskov: Hudozhestvennaja literatura. [Eng. trans. Rabelais and His World. Pomorska, Krystina (ed.). Cambridge: MIT Press, 1968.]

Baroni, Mario 1998. Sign conceptions in music from the Renaissance to the early 19th century. In: Posner et al. 1998: 1326-1330.

Barthes, Roland; Havas, Roland 1977. Ascolto. In: Enciclopedia Einaudi, vol. 1. Turin: Einaudi, 982-991.

Böhme-Dürr, Karin 1997. Technische Medien der Semiose. In: Posner et al. 1997: 357-384.

Bouissac, Paul (ed.) 1998. Encyclopedia of Semiotics. New York: Oxford University Press.

Colapietro, Vincent Michael 1989. Peirce's Approach to the Self: A Semiotic Perspective on Human subjectivity. Albany: State University of New York Press.

Foucault, Michel 1970. L'ordine del discorso. Trans. Fontana, A. Torino: Einaudi. Gallo, Franco Alberto 1997. Sign conceptions in music in the Latin Middle Ages. In: Posner et al. 1997: 1060-1065.

Gould, Stephen Jay; Vrba, Elizabeth S. 1982. Exaptation - a missing term in the science of form. Paleobiology 8(1): 4-15.

Hardwick, Charles S. (ed.) 1977. Semiotic and Significs: The Correspondence between Charles S: Peirce and Victoria Lady Welby. Bloomington: Indiana University Press.

Hjelmslev, Louis 1953. Prolegomena to a Theory of Language. Baltimore: Waverly Press.

Hoffmeyer, Jesper 1998. Biosemiotics. In: Bouissac 1998: 82-84.

Jakobson, Roman 1963. Essais de linguistique générale. Paris: Minuit.

Johansen, Jørgen Dines 1998. Hjelmslev and glossematics. In: Posner et al. 1998: 2272-2289.

Keeley, Brian L. 1998. Artificial life. In: Bouissac 1998: 48-51.

Kull, Kalevi 2002. A sign is not alive - a text is. Sign Systems Studies 30(1): 327-336.

Langhoff, Volker 1997. Zeichenkonzeptionen in der Medizin der griechischen und römischen Antike. In: Posner et al. 1997: 912-921.

Levinas, Emmanuel 1972. Humanisme de l'autre homme. Montpellier: Fata Morgana.

Lomuto, Michele; Ponzio, Augusto 1997. Semiotica della musica. Bari: Graphis.

Lucid, Daniel P. (ed.) 1977. Soviet Semiotics: An Anthology. Baltimore: John Hopkins University Press.

Martinet, André 1960. Eléments de linguistique générale. Paris: Librairie Armand Colin.

Maturana, Humberto R.; Varela, Francisco J. 1980. Autopoiesis and Cognition: The Realization of the Living. Dordrecht: D. Reidel.

Mazzola, Guerino 2003. Semiotische Aspekte der Musikwissenschaft: Musiksemiotik. In: Posner et al. 2003.

Morris, Charles William 1938. Foundations of the Theory of Signs. (International Encyclopedia of Unified Science 1(2). Chicago: University of Chicago Press. 
- 1964. Signification and Significance: A Study of the Relations of Signs and Values. Cambridge: MIT Press.

Münch, Dieter; Posner, Roland 1998. Morris, his predecessors and followers. In: Posner et al. 1998: 2204-2233.

Peirce, Charles S. 1931-1966. Collected Papers, ed. Charles Hartshorne, Paul Weiss and Arthur W. Burks. 8 vols. Cambridge: Belknap Press, Harvard University Press. [Cited as $C P$ followed by volume and paragraph numbers.]

Peschl, Markus 1998. Artificial intelligence. In: Bouissac 1998: 44-46.

Petrilli, Susan 1986. On the materiality of signs. Semiotica 62(3/4): 223-245.

- 1997. Towards interpretation semiotics. In: Capozzi, Rocco (ed.), Reading Eco: An Anthology. Bloomington: Indiana University Press, 121-136.

- 1998a. Su Victora Welby. Significs e filosofia del linguaggio. Naples: Edizioni Scientifiche Italiane.

- 1998b. Teoria dei segni e del linguaggio. Bari: Graphis. [2 ed. 2001.]

— 1999a. About and Beyond Peirce. Semiotica 124(3/4): 299-376.

- 1999b. Charles Morris's biosemiotics. Semiotica 127(1/4): 67-102.

Petrilli, Susan; Ponzio, Augusto (2002). Semiotics Unbounded. Interpretive Routes through the Open Network of Signs. Toronto: Toronto University Press (forthc.).

Ponzio, Augusto 1988. Rossi-Landi e la filosofia del linguaggio. Bari: Adriatica.

- 1993. Signs, Dialogue, and Ideology. Petrilli, S. (ed.). Amsterdam: John Benjamins.

- 1994. Scrittura dialogo alterità: Fra Bachtin e Lévinas. Florence: La Nuova Italia.

- 1997. Metodologia della formazione linguistica. Bari: Laterza.

- 1999. La comunicazione. Bari: Graphis.

- 2003. Modeling, dialogue, and globality: Biosemiotics and semiotics of self. 1. Semiosis, modeling, and dialogism. Sign Systems Studies 31(1): 25-63.

Ponzio, Augusto; Calefato, Patrizia; Petrilli, Susan 1999. Fondamenti di filosofia del linguaggio. Bari: Laterza.

Ponzio, Augusto; Petrilli, Susan 2000. Il sentire nella comunicazione globale. Rome: Meltemi.

- 2003. Semioetica. Rome: Meltemi.

Posner, Roland 1997a. Semiotics and its presentation in this Handbook. In: Posner et al. 1997: 1-14.

— 1997b. Pragmatics. In: Posner et al. 1997: 219-246.

Posner, Roland; Robering, Klaus 1997. Syntactics. In: Posner et al. 1997: 14-83.

Posner, Roland; Robering, Klaus; Sebeok, Thomas A. (eds.) 1997-2003. Semiotik/Semiotics: A Handbook on the Sign-Theoretic Foundations of Nature and Culture, vols. 1, 2, and 3. Berlin: Walter de Gruyter.

Riethmüller, Albrecht 1997. Zeichenkonzeptionen in der Musik der griechischen und römischen Antike. In: Posner et al. 1997: 893-900.

Robering, Klaus 1997. Semantik. In: Posner et al. 1997: 83-219.

Rossi-Landi, Ferruccio 1967-1972. Ideologie. Roma: Edizioni di Ideologie.

- 1975. Linguistics and Economics. The Hague: Mouton.

- 1983 [1968]. Language as Work and Trade. South Hadley: Bergin and Garvey. 
- 1985. Metodica filosofica e scienza dei segni. Milan: Bompiani.

- 1992. Between Signs and Non-signs, intro. and ed. S. Petrilli. Amsterdam: John Benjamins.

- 1994 [1972]. Semiotica e ideologia. Ponzio, Augusto (ed.). Milan: Bompiani.

Rudy, Stephen 1986. Semiotics in the U.S.S.R. In: Sebeok, Thomas A.; UmikerSebeok, Jean (eds.), The Semiotic Sphere. New York: Plenum Press, 555-582.

Ruse, Michael 1998a. Evolution. In: Bouissac 1998: 223-225.

- 1998b. Exaptation. In: Bouissac 1998: 225-226.

Scheffczyk, Adelhard 1998. Zeichenkonzeptionen in der Allgemeinen Philosophie vom 19. Jahrhundert bis zur Gegenwart. In: Posner et al. 1998: 1428-1465.

Schmitz, H. Walter 1998. Die Signifik. In: Posner et al. 1998: 2112-2117.

Sebeok, Thomas A. 1979. The Sign and its Masters. Austin: University of Texas Press.

- 1986. I Think I am a Verb: More Contributions to the Doctrine of Signs. New York: Plenum Press.

- 1991a. A Sign is Just a Sign. Bloomington: Indiana University Press. [2nd edition 2001].

- 1991b. American Signatures: Semiotic Inquiry and Method. Norman: University of Oklahoma Press.

- 1994. Signs: An Introduction to Semiotics. Toronto: Toronto University Press.

- 1997. The evolution of semiosis. In: Posner et al. 1997: 436-446.

- 2001. Global Semiotics. Bloomington: Indiana University Press.

Sebeok, Thomas A.; Danesi, Marcel 2000. The Forms of Meanings: Modeling Systems Theory and Semiotic Analysis. Berlin: Mouton de Gruyer.

Sebeok, Thomas A.; Petrilli, Susan; Ponzio, Augusto 2001. Semiotica dell'io. Rome: Meltemi.

Sebeok, Thomas A.; Umiker-Sebeok, Jean (eds.) 1992. Biosemiotics: The Semiotic Web 1991. Berlin: Mouton de Gruyter.

Tarasti, Eero 1998. Sign conceptions in music from the 19th century to the present. In: Posner et al. 1998: 1625-1655.

Threadgold, Terry 1997. Social media of semiosis. In: Posner et al. 1997: 384404.

Thompson, Evan 1998. Autopoiesis. In: Bouissac 1998: 53-55.

Uexküll, Jakob von 1909. Umwelt und Innenwelt der Tiere. Berlin: Springer.

- 1992 [1934]. A stroll through the worlds of animals and men. Semiotica 89(4): 319-391.

Varela, Francisco; Maturana, Humberto R.; Uribe, Ricardo 1974. Autopoiesis: The organization of the living systems, its characterization and a model. BioSystems 5: 187-196.

Welby, Victoria 1983 [1903]. What is Meaning? (Studies in the Development of Significance). Eschbach, Achim (ed.). Amsterdam: John Benjamins.

- 1985 [1911]. Significs and language (The Articulate Form of Our Expressive and Interpretative Resources). Schmitz, H. Walter (ed.). Amsterdam: John Benjamins. 


\section{Моделирование, диалог, глобальность:}

\section{биосемиотика и семиотика самости.}

\section{2. Биосемиотика, семиотика самости и семиоэтика}

Основные современные подходы в семиотических исследованиях противоречат идее индивида как обособленной и самодостаточной единицы. Тело организма в микро- и макрокосмосе не является изолированной биологической единицей и не принадлежит отдельному индивиду. Тело является организмом, который живет в отношениях с другими телами, таким образом находясь как бы между телами и во взаимной зависимости. Такое понимание тела находит подтверждение в культурных практиках и в мировоззрениях, которые основываются на межтелесности, взаимной зависимости, презентации и открытости - хотя к настоящему времени они почти исчезли. Подход к семиотике как к чему-то глобальному и в то же время способному преодолеть иллюзорную идею об определенных и окончательных границах идентичности, предполагает диалог и инаковость (otherness). Инаковость заставляет индивида сомневаться в направленности на всеобщую закрытость и постоянно себя переформировывать в процессе, соотносимом с “бесконечностью” (как учит Эммануэль Левинас) или в “бесконечном семиозисе” (следуя Чарльзу Пирсу). Вторая тема - соотнесенность человека и машины в антропосемиозисе и исходящие из этого сценарии будущего. Цель данного совместного (с А. Понзио) исследования — развитие глобальной семиотики в направлении “семиоэтики”.

\section{Modelleerimine, dialoog, globaalsus:} biosemiootika ja enesesemiootika.

\section{Biosemiootika, enesesemiootika ja semioeetika}

Peamised praegusaegsed vaated semiootilises uurimistöös räägivad vastu indiviidi kui eraldatud ja eneseküllase üksuse ideele. Organismi keha mikro- ja makrokosmoses ei ole isoleeritud bioloogiline üksus, ta ei kuulu üksikolendile, ei ole omaette eraldatud ja eneseküllane sfäär. Keha on organism, mis elab suhetes teiste kehadega, olles seega kehadevaheline ja vastassõltuvuses. Taoline keha mõiste leiab kinnitust kultuurilistes praktikates ja maailmavaadetes, mis põhinevad kehadevahelisusel, vastassõltuvusel, esitusel ja avatusel - kuigi praeguseks on need peaaegu väljasurnud. Lähenemine semiootikale kui globaalsele ja samaaegselt suutelisele ületama illusoorset ideed identiteedi kindlakujuliste ja lõplike 
piiride kohta, eeldab dialoogi ja teistsugusust (otherness). Teistsugusus sunnib identiteeti kahtlema suunitluses üldisele suletusele ja end aina ümber korraldama "lõpmatusega" seonduvas protsessis, nagu Emmanuel Levinas õpetab, või "lõpmatus semioosis" Charles Peirce'i järgides. Teine teema ses artiklis on inimese ja masina suhestumine antroposemioosis ning sellest tulenevad tulevikustsenaariumid. Käesoleva ühisuurimuse eesmärk on globaalsemiootika arendamine "semioeetika" suunas. 